\title{
PRODUK KERUPUK PANGSIT HERBAL SEBAGAI UPAYA MENINGKATKAN KESEJAHTERAAN PENGUSAHA HOME INDUSTRY DI KOTA MEDAN
}

\author{
Mastarina Barus $^{1 *}$, Adikahriani ${ }^{1}$ \\ ${ }^{1}$ Jurusan Pendidikan Kesejahteraan Keluarga, Fakultas Teknik, Universitas Negeri Medan, \\ Jl. Willem Iskandar pasar V-Kotak Pos No. 1589-Medan 20221 \\ *Penulis Korespodensi: mastarina@yahoo.co.id
}

\begin{abstract}
Abstrak
Tujuan Kegiatan ini adalah pengembangan usaha pengolahan melalui kerupuk pangsit. Kegiatan dilaksanakan mulai bulan April-November 2016. Metode pelaksanaan kegiatan adalah pendidikan, pelatihan produksi, pelatihan manajemen usaha, penggunaan mesin dan pendampingan. Mitra kegiatan yaitu home industri Ofita dan home industri Uci Snack di Kota Medan. Target luaran kegiatan ini adalah mengembangkan usaha mita melalui pembuatan kerupuk pangsit herbal. Hasil kegiatan yang diperoleh yaitu mitra memiliki pengetahuan tentang pengolahan kerupuk pangsit herbal, mitra berpartisipasi aktif, mitra terampil menggunakan alat pencetak kerupuk pangsit herbal. Produksi mitra semakin baik dan penghasilan mitra juga semakin meningkat.
\end{abstract}

Kata Kunci : Home Industri, Kerupuk, Pangsit, Herbal

\begin{abstract}
The purpose of this activity is the development of processing business through dumpling crackers. Activities are conducted from April to November 2016. The method of activity implementation is education, production training, business management training, machine use and mentoring. Partners of the activities of home industry Ofita and home industry Uci Snack in the city of Medan. The outcome target of this activity is to develop the business of mita through the manufacture of herbal dumpling crackers. The result of the activity obtained is that the partners have knowledge about the processing of herbal dumpling crackers, actively participating partners, skilled partners using herbal dumpling cracker tool. Partner production is getting better and partner income is also increasing.
\end{abstract}

Keywords: Home Industry, Crackers, Dumplings, Herbs

\section{PENDAHULUAN}

\section{Analisis Situasi}

Kerupuk adalah jenis pangan yang digemari di Indonesia. Berbagai kalangan menyukai jenis pangan ini baik golongan rendah maupun golongan yang tinggi. Kerupuk sangat beragam dalam bentuk, ukuran, bau, warna, rasa, kerenyahan, ketebalan dan nilai gizinya. Perbedaan ini bisa disebabkan pengaruh budaya daerah penghasil kerupuk, bahan baku dan bahan tambahan yang digunakan serta alat dan cara pengolahannya. Komposisi bahan sendiri beserta pengolahannya akan sangat mempengaruhi kualitas kerupuk, dimana komposisi bahan ini juga mempengaruhi pengembangan pada kerupuk tersebut (Anonim $^{(\mathrm{b})}, 2011$ ).

Kerupuk Pangsit adalah salah satu jenis makanan kering yang sering dijumpai pada bakso- bakso kuah, yang ketika digigit sangat renyah dan pada bagian tengahnya yang gemuk terdapat bahan isi yang rasanya gurih. Daya tarik dari pangsit sendiri terletak pada kerenyahannya tersebut sehingga membuat banyak orang yang sangat suka padanya yang apabila memakan bakso pasti akan terasa kurang lengkap jika tanpa pangsit ini. Uniknya dalam perkembangannya juga ada camilan sejenis yaitu berupa kerupuk yang serupa dengan pangsit dan banyak yang menyebutnya sebagai kerupuk kulit pangsit (Fauziah, 2014).

Kerupuk pangsit seperti ini berbeda dengan pangsit biasa, karena kerupuk tersebut hanya diambil pada bagian yang renyahnya saja sehingga tidak memiliki bahan isi yang terlihat mengembung seperti pangsit pada umumnya. Jika dilihat dari tekturnya kerupuk pangsit sama seperti bagian tepi atau kulit pada pangsit biasa yaitu kering, tipis dan seperti ada 
gelembung-gelembung kecil pecah-pecah, dan jika dilihat dari rasanya juga sangat gurih. Selain itu juga cocok untuk dijadikan camilan dirumah maupun hidangan untuk tamu yang sedang berkunjung kerumah (Fauziah, 2014).

Herbal adalah tanaman atau tumbuhan yang mempunyai kegunaan atau nilai lebih dalam pengobatan. Dengan kata lain, semua jenis tanaman yang mengandung bahan atau zat aktif yang berguna untuk pengobatan bisa digolongkan sebagai herbal. Herbal dapat berupa bahan makanan yang ternyata kita makan sehari-hari. Makanan herbal adalah makanan yang mengandung zat-zat yang dibutuhkan untuk kesehatan tubuh. Makanan herbal kaya akan kandungan zat-zat gizi. Makanan pokok seperti padi dan jagung dapat juga digolongkan sebagai herbal, begitu juga dengan buah, sayuran, dan rempah-rempah (Anonim $\left.^{(\mathrm{c})}, 2015\right)$.

Dalam pengolahan kerupuk pangsit selama ini hanya menggunakan bahan dasar tepung terigu, telur, mentega dan air. Untuk meningkatkan rasa kerupuk pangsit dapat di manfaatkan berbagai buah dan sayuran yang tergolong sebagai makanan herbal, sehingga kerupuk pangsit yang dihasilkan dapat meningkatkan kesehatan bagi yang suka mengkonsumsinya. Makanan herbal yang dapat di gunakan sebagai fortifikasi kerupuk pangsit yaitu wortel, bayam, kentang, ubi rambat dan lain-lain.

Berdasarkan hal tersebut maka perlu memberikan pelatihan kepada mitra untuk mengembangkan usahanya. Salah satu upaya yang perlu dilakukan adalah memberikan pendidikan, sosialisasi, pelatihan produksi dan manajemen usaha guna meningkatkan penghasilan mitra. Upaya yang dapat dilakukan adalah pengolahan kerupuk pangsit menjadi kerupuk herbal, sehingga setiap saat dapat dikonsumsi oleh masyarakat yang dapat meningkatkan kesehatan dan perbaikan gizi terutama untuk anak-anak yang sangat membutuhkan makanan sehat untuk mencegah berbagai penyakit.

Permintaan pasar terhadap bahan pangan tidak akan pernah sepi, salah satunya permintaan pasar terhadap kerupuk masih tinggi. Dengan banyaknya permintaan pasar terhadap kerupuk, semakin banyak industri kerupuk baru berskala rumah tangga. Dengan demikian semakin tinggi persaingan pasar terhadap kerupuk. Sedangkan industri rumah tangga memiliki beberapa keterbatasan seperti keterbatasan modal, jenis kerupuk yang diproduksi, skala produksi, lama produksi dan pemasaran produk (Anonim $\left.{ }^{(a)}, 2011\right)$.

Dalam pembuatan kerupuk pangsit masih belum sesuai dengan kebutuhan yang diinginkan, karena teknik mengolah masih secara manual, oleh karena perlu memberikan mesin pencetak kerupuk pangsit herbal. Pemberian mesin pencetak kerupuk pangsit ini bertujuan untuk memperpendek waktu pengolahan, meningkatkan produk dan kualitas, dan memberikan hasil yang lebih baik serta membantu pekerja dalam melakukan proses pengolahan yang lebih aman (Nurmin, 2007).

\section{Permasalahan Mitra}

Mitra kegiatan ini terdiri dari 2 mitra yaitu home industri Ofita dan home industri Uci Snack yang berada di Kota Medan berjarak $16 \mathrm{~km}$ dari Unimed, merupakan salah satu kelompok usaha yang memproduksi kerupuk pangsit. Home industri ini menggunakan bahan baku dari tepung terigu, dalam pengolahan kerupuk pangsit perharinya bisa mencapai $50 \mathrm{~kg}$. Peralatan yang digunakan untuk mengolah kerupuk pangsit masih sederhana, seperti untuk pencetakan kerupuk pangsit mitra masih menggunakan ampia kecil manual. Kerupuk pangsit ini dikemas dalam kemasan platik kecil dengan harga Rp 1.000,dan isi $1 \mathrm{~kg}$ harga jualnya $\mathrm{Rp} 35.000,-$. Hasil usaha home industri ini digemari oleh masyarakat karena rasanya yang gurih dan harganya juga dapat dijangkau terutama anak-anak. Sistem pemasarannya masih terbatas, hanya dititipkan di warung-warung bakso, dijual di pasar tradisional, di jual oleh pedagang kaki lima yang ada di sekitar sekolahan dan terkadang dijual kepada pengumpul. Keberadaan usaha kerupuk pangsit ini sebenarnya sangat menguntungkan bagi masyarakat sekitarnya karena dapat menyerap tenaga kerja sekitar 4-10 orang. Pekerja pada home industri ini merupakan pekerja lepas atau pekerja harian dengan gaji perhari Rp 15.000,- perorang.

Berdasarkan kondisi mitra tersebut, yang menjadi permasalah mitra adalah diperlukannya teknologi tepat guna yaitu mesin pencetak kerupuk pangsit dengan menggunakan mesin dan pengembangan produk yaitu kerupuk pangsit herbal sehingga dapat memproduksi kerupuk pangsit semakin banyak, dengan menggunakan teknologi tepat guna, murah dan mudah untuk melakukannya.

Bila dilihat kondisi manajemen yang diterapkan oleh mitra home industri ini masih menggunakan manajemen sederhana secara kekeluargaan, dimana pengelolaan administrasi yang meliputi pengaturan kerja, pembiayaan, produksi dan SDM masih dilakukan secara sederhana. Untuk pengelolaan usaha mitra ini, semuanya masih di pegang oleh pemilik usaha, baik pengadaan bahan baku, pengelolaan produksi, tenaga kerja, dan penjualan. Meskipun menganut manajemen kekeluargaan, sistem pembagian kerja sudah teroganisir dengan baik, artinya masing-masing pekerja sudah mempunyai tugas dan tanggungjawab untuk pekerjaan masing-masing.

Melihat potensi home industri kerupuk pangsit ini cukup besar dan didukung dengan potensi sumberdaya alam. Mudahnya mendapatkan bahan baku disekitar tempat tinggal mitra kiranya diperlukan suatu upaya untuk memberdayakan home industri. Melalui teknologi tepat guna dan memberikan pengetahuan, pelatihan produksi, manajemen usaha dan pemasaran. Kegiatan yang dilakukan yaitu memberikan pengetahuan tentang kandungan gizi kerupuk pangsit herbal, teknik pengolahan kerupuk pangsit menjadi kerupuk pangsit herbal, manajemen usaha dan teknologi tepat guna, penggunakan mesin pencetak kerupuk pangsit yang secara langsung dapat mempengaruhi proses usaha mitra ini. Produk home industri ini akan menghasilkan kerupuk pangsit dari 
herbal yang berkualitas, gizi tinggi yang dapat meningkatkan produksi, sehingga dapat meningkatkan pendapatan mitra.

\section{Target dan Luaran}

1. Luaran kegiatan :

a. Mesin Pencetak kerupuk pangsit herbal

b. Kerupuk pangsit herbal

2. Spesifikasi kerupuk pangsit herbal:

a. Memiliki kandungan gizi : karbohidrat, protein, vitamin A, C dan B kompleks, kalsium, zat besi, magnesium, fosfor, sodium, serat, dan zat antioksidan.

b. Tahan lama dan higienis.

\author{
Spesifikasi Alat \\ Spesifikasi Mesin Pencetak Kerupuk Pangsit Herbal: \\ - Tipe MJ180 \\ - Kapasitas ; 20-25 kg / jam \\ - Listrik : 370 watt, $220 \mathrm{~V}$ \\ - Berat : $32 \mathrm{~kg}$ \\ - Dimensi : 365 x 390 x 395 mm \\ - Body kokoh \\ - Ukuran Cetakan : 3 mm
}

\section{METODE PELAKSANAAN}

Berdasarkan permasalahan yang telah dikemukakan, maka dalam kegiatan ini metode pendekatan yang digunakan adalah metode pendidikan, metode pelatihan produksi, pelatihan manajemen usaha, penggunaan mesin dan pendampingan., metode pendekatan untuk memecahkan masalah mitra sebagai berikut :

1. Memberikan pengetahuan tentang kandungan zat gizi kerupuk pangsit herbal dengan metode pendidikan dan penyuluhan pada home industri. Kerupuk pangsit herbal mempunyai kandungan gizi karbohidrat, vitaman A dan serat tinggi, sehingga di mungkinkan untuk diolah menjadi produk pangan.

2. Memberikan teknologi pengolahan pangan untuk dijadikan kerupuk pangsit herbal yang aman untuk dikonsumsi, dengan metode pendidikan, penyuluhan dan pelatihan produksi. Tujuan pelatihan produksi ini, memberikan pengetahuan kepada mitra, teknik pengolahan kerupuk pangsit herbal, sanitasi dan higiene makanan untuk meningkatkan mutu dan keamanan pangan, sehingga dapat di jadikan peluang pengembangan usaha.

3. Memberikan mesin pencetak kerupuk pangsit herbal dan metode pendampingan penggunaan mesin pencetak kerupuk pangsit herbal pada mitra. Mesin ini efektif dan efisien, operasinya mudah, sehingga dapat mencetak kerupuk pangsit herbal dengan cepat.

4. Memberikan teknik pengolahan kerupuk pangsit herbal dan keamanan pangan dengan metode sosialisasi dan pelatihan produksi. Makanan yang di produksi dengan tujuan untuk dijual kepada masyarakat umum, seharusnya dijamin mutunya baik serta aman untuk dikonsumsi.

5. Memberikan pelatihan manajemen usaha, dengan tujuan untuk meningkatkan keterampilan pemilik usaha (mitra) dalam menerapkan manajemen di bidang organisasi, produksi, keuangan, administrasi, harga jual produk, konsumen dan teknik pemasaran. Pelaku usaha ini biasanya adalah pemilik usaha yang memiliki fungsi ganda, karena itu manager dalam usaha ini berhadapan langsung dengan semua hal yang berkaitan dengan usaha, produksi, sumberdaya, pemasaran, pengembangan usaha dan lain-lain.

Materi pelatihan yang akan diberikan adalah:

- Pengetahuan dasar wirausaha

- Mengenali posisi usaha

- Konsep dasar marketing

- Komunikasi efektif dalam penjualan

- Fokus pada keunggulan produk

- Manajemen pegawai

- Monitoring pegawai

- Manajemen biaya UKM

- Menentukan harga produk dan harga jual

- Manajemen waktu dalam usaha

\section{HASIL DAN PEMBAHASAN}

Dalam bisnis produk makanan yang paling berpeluang tinggi untuk dikembangkan dan di pasarkan pada area lingkup yang luas adalah makan ringan. Produk ini memiliki kelebihan tersendiri dibandingkan produk makanan lain. Makanan ringan atau lebih dikenal masyarakat dengan sebutan snack /jajanan biasanya berbentuk barang kering yang ringan dan dapat dikemas dengan berbagai bentuk wadah yang menarik, plastik maupun kertas yang dapat dihias dengan berbagai desain produk yang menarik. Plastik dan kertas juga bahan yang mudah didapat dan murah dipasaran, sehingga dapat menekan pengeluaran dalam proses produksi (Misnal, 2015).

Makanan berbasis gandum atau tepung terigu telah menjadi makanan pokok banyak negara. Ketersediaannya yang melimpah di pasaran dunia, proteinnya yang tinggi, harganya yang relatif tidak mahal dan pengolahannya yang praktis dan mudah telah menjadikan makanan berbasis tepung terigu merambah cepat ke berbagai negara. Di dalam tepung terigu terdapat Gluten, yang secara khas membedakan tepung terigu dengan tepung tepung lainnya. Gluten adalah suatu senyawa pada tepung terigu yang bersifat kenyal dan elastis, yang diperlukan dalam pembuatan roti agar dapat mengembang dengan baik, yang dapat menentukan kekenyalan mie serta berperan dalam pembuatan kulit pangsit supaya tidak mudah robek (Misnal, 2015).

Pangsit kering atau juga di sebut pangsit goreng mrupakan salah satu makanan yang sudah dikenal oleh masyarakat Indonesia. Makanan ringan ini akrap dijadikan tambahan pada bakso yang menambah kenikmatan saat memakannya. Selain sebagai 
tambahan untuk bakso pangsit juga bisa dijadikan camilan nikmat yang dinikmati bersama sama maupun dinikmati sendiri (Misnal, 2015).

Salah satu kelebihan pangsit goreng yaitu dapat dijadikan camilan ringan dapat bertahan lebih lama sehingga dapat di pasarkan ke wilayah pada area yang luas. Sifat ringan dan tidak terlalu mengenyangkan di perut membuat produk ini dapat di konsumsi dalam jumlah yang banyak dan membuat seseorang ketagihan sehingga jika kita dapat menjalankan bisnis ini dengan strategi bisness plan yang benar dapat raup untung yang besar dalam jangka waktu yang lama, (Misnal, 2015).

Sesuai dengan permasalahan yang dihadapi oleh mitra, maka kegiatan ini dilakukan dalam bentuk transfer iptek yang dilakukan berupa sosialisasi, pelatihan, dan pendampingan kepada mitra. Kegiatan yang dilakukan diawali dengan pertemuan tim pelaksanan untuk pembagian tugas masing-masing tim pelaksana. Kemudian penetapan jadwal pelaksanaan kegiatan. Tersusunnya jadwal kegiatan, maka tim pelaksana dapat melaksanakan tugas sesuai dengan yang sudah disepakati. Selanjutnya tim pelaksana menyiapkan bahan dan peralatan yang dibutuhkan untuk pelaksanaan kegiatan. Pada gambar 1 dapat dilihat mesin yang diserahkan pada mitra.

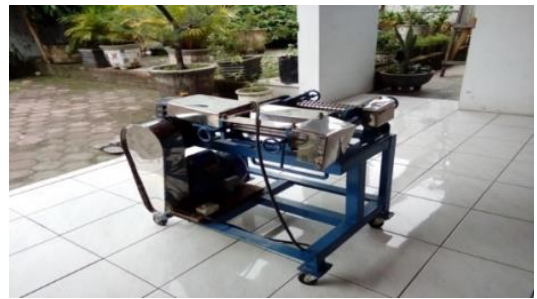

Gambar 1. Mesin pencetak kerupuk pangsit herbal

Kegiatan yang dilakukan ditanggapi positif oleh mitra. Dengan adanya tanggapan positif dari mitra kegiatan bisa berjalan lancer, sehingga semua program dapat berjalan sesuai dengan waktu yang telah ditetapkan. Langkah berikutnya setelah dilakukan koordinas dan sosialisasi yaitu mengadakan pelatihan cara membuat kerupuk pangsit herbal, serta menggunakan alat pencetak yang digunakan untuk pencetak kerupuk pangsit herbal.

Sebelum dilakukan praktek pembuatan kerupuk pangsit herbal terlebih dahulu dilakukan penyerahan alat-alat dan bahan bahan baku pengolahan kerupuk pangsit herbal kepada mitra yang disaksikan oleh tim dari LPM Unimed dan perangkat Kelurahan. Penyerahan alat-alat dan bahan baku secara simbolik dilakukan oleh Tim pelaksana dan kepada Mitra. Pada gambar 2 dan 3 dapat dilihat penyerahan alat kepada mitra.

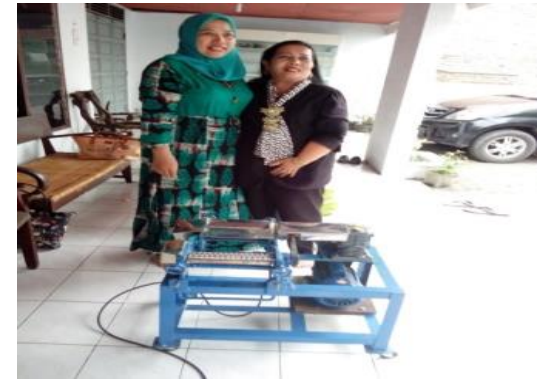

Gambar 2. Serah terima peralatan dan bahan kepada mitra 1

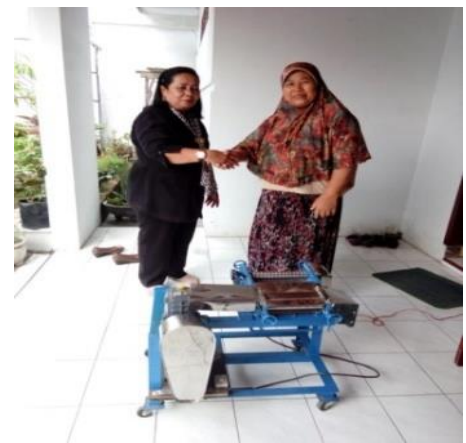

Gambar 3. Serah terima peralatan dan bahan kepada mitra 2

Kegiatan pelatihan membuat kerupuk pangsit herbal, diawali dengan penjelasan teori terlebih dahulu. Setelah teori diberikan kepada mitra selanjutnya diadakan tanya jawab untuk membahas halhal yang dirasa belum dipahami oleh mitra. Selanjutnya jika teori dipandang cukup dipahami oleh mitra maka dilaksanakan kegiatan praktik membuat kerupuk pangsit herbal. Pada gambar berikut ini dapat dilihat kegiatan pelaksana kegiatan dengan mitra.

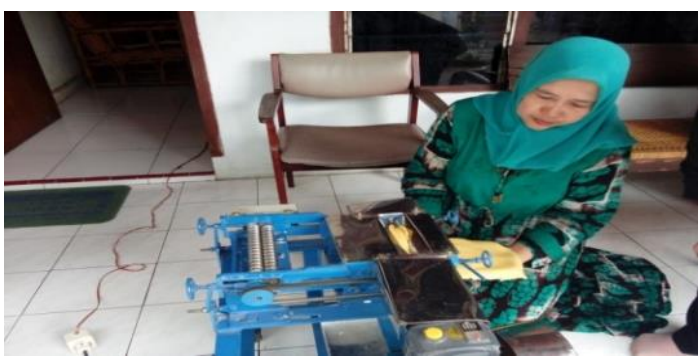

Gambar 4. Mitra 1 sedang menggunakan mesin pencetak kerupuk pangsit herbal

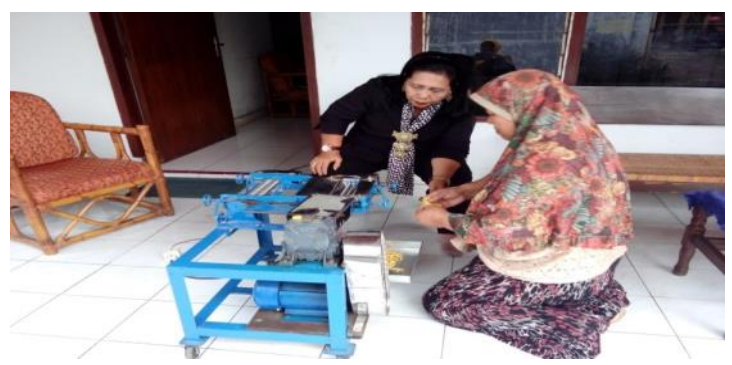

Gambar 5. Ketua pelaksana dan Mitra 2 sedang menggunakan mesin pencetak kerupuk pangsit herbal 


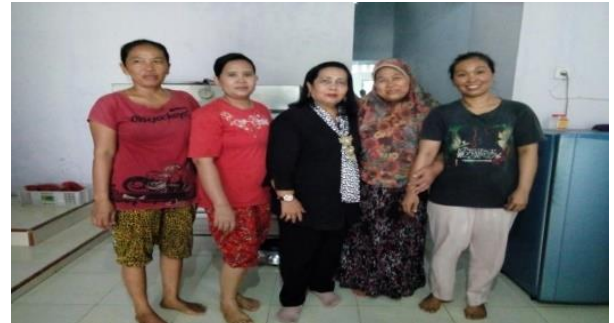

Gambar 6. Foto bersama Ketua pelaksana dan karyawan mitra

Hasil pelatihan adalah berupa produk kerupuk pangsit herbal yang perlu mendapat penilaian dari Penilaian terhadap kualitas produk didasarkan pada pedoman acuan yang telah ditetapkan oleh Tim Pelaksana. Pada gambar berikut ini dapat dilihat hasil produksi mitra.

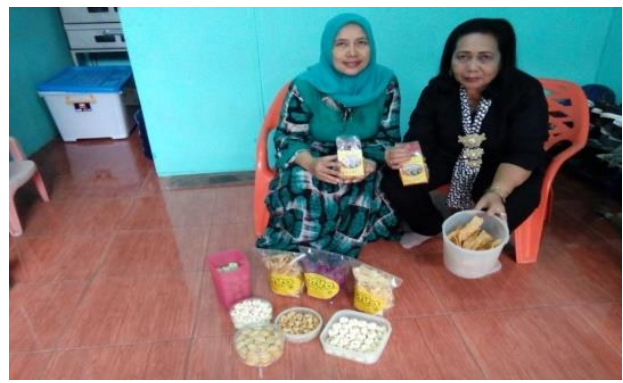

Gambar 7. Hasil produksi mitra 1

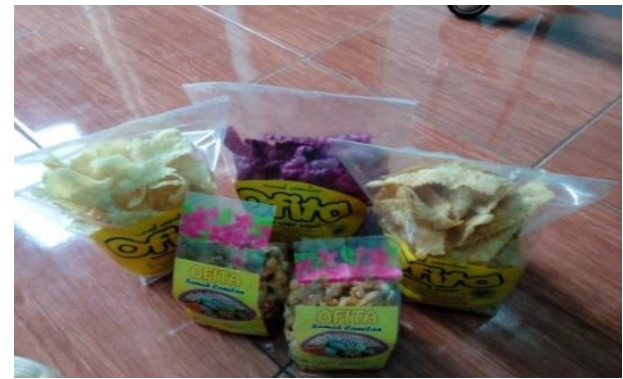

Gambar 8. Hasil produksi mitra 1 Kerupuk Pangsit Herbal dengan lebel OFITA

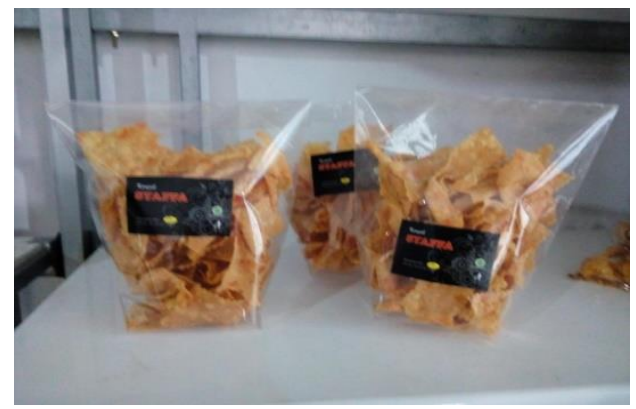

Gambar 9. Hasil produksi mitra 2 Kerupuk Pangsit Herbal dengan lebel SYAFFA

Secara umum kegiatan berhasil dengan baik, ditinjau dari keberhasilan yang sudah tercapai yaitu:

1. Mitra memiliki pengetahuan tentang kerupuk pangsit herbal
2. Mitra berpartisipasi aktif pada kegiatan.

3. Mitra terampil menggunakan alat pencetak kerupuk pangsit herbal.

4. Produksi mitra semakin baik.

5. Penghasilan mitra semakin meningkat.

6.

\section{KESIMPULAN}

Kesimpulan yang dapat diperoleh dari pelaksanaan pengabdian kepada masyarakat adalah:

1. Tingkat partisipasi yang tinggi dari mitra program pengabdian kepada masyarakat memberikan dampak positif bagi pelaksanaan program, terlihat dari pelatihan dan pendampingan, manajemen produksi, dapat berjalan dengan baik.

2. Pelaksanaan kegiatan menghasilkan luaranluaran yang diharapkan oleh program pengabdian kepada masyarakat.

3. Mitra sudah dapat mengolah kerupuk pangsit herbal.

4. Tim LPM dan pemerintah setempat memantau, mendampingi dan memonitoring kegiatan.

\section{UCAPAN TERIMA KASIH}

Ucapan terima kasih kepada Kemenristek Dikti atas pemberian dana hibah tahun 2016 dan terima kasih kepada LPM Unimed serta kepada mitra yang telah membantu dalam pelaksanaan kegiatan ini.

\section{DAFTAR PUSTAKA}

Anonim $^{\text {(a) }}$. 2011. Pengertian kerupuk. Diakses tanggal 22 April 2015. http://www.iptek.net.id

Anonim $^{(b)}$. 2010. Pengertian Kerupuk. Diakses tanggal 20 April 2015. http://free-download-latestbooks.blogspot.com

Anonim $^{(\mathrm{c})}$. 2015. Lima Jenis Makanan Sehari-hari yang Bersifat Herbal. Diakses tanggal 23 April 2015. http://www.smallcrab.com.

Fauziah L. 2014. Cara membuat Kerupuk Pangsit Renyah dan gurih. Diakses tanggal 23 April 2015. http://cemilan-rakyat.blogspot.com.

Misnal. 2015. Pemasaran keripik Pangsit. Diakses tanggal 2 Desember 2016. http:// mahmudielmisnal.blogspot.co.id/

Nurmin. 2007. Perancangan Alat Pemotong Singkong dengan Kapasitas $100 \mathrm{KG} / \mathrm{JAM}$. Diakses 22 Maret 2015. http://digilib.polban.ac.id. 